
www.globaljournalseries.com; globaljournalseries@gmail.com

\title{
LEADERSHIP STYLES OF SOCIAL STUDIES TEACHERS AND ACADEMIC ACHIEVEMENT OF JUNIOR SECONDARY SCHOOL STUDENTS IN SOCIAL STUDIES IN CALABAR METROPOLIS, CROSS RIVER STATE NIGERIA.
}

ODEY, EDWARD OGAR AND ESTHER EDWARD ODEY

(Received 15 July 2021 Revision Accepted 23, August 2021)

\begin{abstract}
This study was carried out to determine leadership styles of Social Studies teachers and academic achievement of junior secondary school students in Social Studies in Calabar Metropolis, Cross River State-Nigeria. Ex-post facto research design was adopted. The simple random sampling technique was used in selecting the six public secondary schools used for the study. A sample of two hundred junior secondary school three students (JSS 3) was drawn from the population and used for the study. Three research questions and hypotheses were formulated to guide the study. Data were collected using two researcher made instruments tagged "Social Studies Teachers Leadership Styles Questionnaire (STLSQ) and Social Studies Achievement Test (SOSAT) The Data Collected was analysed using the Analysis of Variance (ANOVA) and the Fisher Least Square Difference (SLD) was used in the multiple comparism. The findings of the study revealed significant differences in the academic achievement of students based on their teachers' leadership styles. Students taught by teachers with autocratic and laissez-faire leadership styles had a lower LSD value compared to students taught by teachers with democratic leadership styles. Students taught by teachers with democratic styles performed academically higher than those taught by teachers with either autocratic or laissez-faire leadership styles. Based on this, it was recommended amongst other things that Social Studies teachers imbibe more of democratic rather than autocratic or laissez faire leadership styles in their classroom and that educational administrator should organize workshop and seminars for teachers on proper classroom management.
\end{abstract}

KEYWORDS: Leadership, Leadership styles, Autocratic, democratic, Laissez faire.

\section{INTRODUCTION}

There is no gainsaying the fact that the ultimate realization of the aims and objectives of education is a function of teachers' variables. The teacher is therefore responsible for translating policies into actions and principles into practice in the classroom interaction with the students (Odey,2014). Besides, Adetula (1993) opined that effective learning results from effective teaching and student's performance is the keyword to justify this. The teacher, in the educational process plan, organises and controls the student's activities and consequently appears

Odey, Edward Ogar, Department of Social Science Education Faculty of Education, University of Calabar, Nigeria.

Esther Edward Odey, Department of Social Science Education Faculty of Education, University of Calabar, Nigeria. 
in the position of a leader.

However, leadership has been observed as fundamental to the success of any group or organization. Behaviours displayed by teachers in the classroom environment during the communication process in teaching activities show their classroom leadership styles (Odey and Odey, 2019). Teachers are classroom leaders and may apply different classroom leadership styles (Ekici, 2004).Therefore, leadership style(s) in the classroom cannot be overemphasized in teaching and learning. It goes a long way in determining performance of both the teachers who is the boss, director, manager administrator and organizer (Amadikwe, 1991).

Moreover, Okoroji, Anyanwu and Ukpere (2014) postulated that the interaction between the teacher and the student is one of the most important aspects of educational process, but the most neglected. Privacy and autonomy enable each teacher to manage and organize his own classroom the way he prefers to handle it. Good \& Brophy (1995) have identified some general attributes of teachers that contribute to their success in socializing students. These attributes include: Social attractiveness, based on a cheerful disposition, friendliness, emotional maturity, sincerity and other qualities that indicate good mental health and personal adjustment. Ego strength, exhibited in self-confidence that allows teachers to be calm in a crisis, listen actively without being defensive, avoid win lose conflicts and maintain a problem-solving orientation. Realistic perception of self and students, without letting perceptions become clouded by romanticism, guilt, hostility or anxiety. Enjoying students while at the same time, maintaining their identity as an adult, a teacher and an authority figure. It is good to be friendly but not overly familiar. It is also important to be comfortable with the group without becoming a group member. Clarity about teacher's role, and comfort in playing them, enables teachers to explain coherently to students what they expect. It is necessary to be patience and determined to work with students who persist in testing limits. Acceptance of individual, though not necessarily all of his or her behavior, and making this attitude clear to students. The ability to state and act on firm but flexible limits based on clear expectations is another perquisite. It is also important to keep rules to a minimum and liberalizing them as students become more independent and responsible over time. Developing these personal qualities and using research-based principles for managing the classroom will set the stage for student socialization and will go a long way toward minimizing the need for disciplinary interventions. According to Paun (1999), studies conducted in the field of classroom management present the teacher authoritative, democratic and Laissezfaire leadership styles. The teacher therefore in some situation makes all the decisions about the organization of the group and the activities performed in the class. The teacher does not share with the students the overall plan of activities, nor the criteria for assessing individual or group performances of the students. On the other hand, the teacher does not participate either too much in the activities. The teacher avoids making decisions alone and encourages the student to participate in the class activities. The students are offered the opportunity to choose from the array of learning activities. The teacher presents the common criteria of assessment and criticism and observes together with the student, acting in a way like a member of the student group. Conversely, a teacher could also decide to be passive as the class leader limiting his participation as much as possible, leaving the students to take all the initiative. The teacher exhibits a friendly attitude but by all he does suggests indifference and non-involvement (Odey and Odey, 2018).

However, Social Studies is one of the core courses offered at the junior secondary school as stipulated in the National Policy on Education (FRN, 2004). Striking at the heart of Social Studies is an educational intent of making students to become knowledgeable and purposeful "responsible citizens" (Udoukpong, Emah and Okon, 2006). Social studies curriculum integrates concepts, processes and ways of thinking drawn from the diverse disciplines of Humanities, Social Sciences and Pure Science. In particular, Social Studies curriculum promotes students growth as individuals and citizens of a nation. Mkpa (2005) confirmed that the implemented curriculum determines the extent to which educational objectives are achieved. Social Studies teaching then require teachers who can create and implement various creative curriculum plans that actively involve students in the learning process. The methodology of style(s) employed by the teacher in instructional delivery may be of great significance in curriculum implementation. Arising from the above, the researcher sought to find out the differences that may exist in junior secondary school Social Studies academic achievement based on the their teachers' leadership styles. 


\section{STATEMENT OF THE PROBLEM}

The major concern of the school organization is the success or effectiveness of teaching/ learning process. Teacher leadership approach is an idea whose time has come to be given proper attention. The unprecedented demands being placed on the schools today require effective and efficient leadership at every level. Yet many schools are still organized as though all the important decisions are made by administrators and carried out by teachers or by the teacher and the students, passive recipient. Besides, the issue of leadership styles in teaching and learning have been raised in many instances by trying to find out the causes of poor standard of education in Nigeria. The present decline in academic achievement coupled with the saying that "No school can be greater than her teachers" is an issue of great concern. It seems to be out of the mind that teachers' leadership style in the classroom may be an outstanding determinant of student academic achievement. It is also pertinent to note that some leadership styles enhance teachers/students relationship while some impose dissatisfaction. It is necessary to determine how each of these leadership styles influences teaching and learning.

\section{SIGNIFICANCE OF THE STUDY}

It is anticipated that the results of this research would be of immense benefit to the teachers, teacher training institutions, curriculum planners, school administrators and students alike.

To the teachers, the results of the study may further give an insight to the role of the teacher in the classroom as a leader in the classroom. He helps in building up the learner's personality and his emotional stability. Learning involves a child's personal experience with the environment and the texture of the learning environment created depends substantially on the teacher.

To the teachers training institutes, findings from this study is expected to provide a basis for improving Social Studies teachers' programmes by focusing on ways to improvement in retraining teachers and would be teachers in effective classroom management; a basis for developing a more effective model for teaching Social Studies. Consequently, when curriculum planners become aware of the new model through seminars and publications, they may apply it as a model in future curriculum planning for effective learning and studying of Social Studies in the classroom. Besides, the study may also identify the causes of poor activity of individuals in Social Studies. It could also alleviate the problems of assigning
Social Studies to unqualified and ineffective teachers in schools.

More so, school administrators may advantage from the results of this research when they study of the results of the study, through its publication, they may utilize them for the enhancement of the teachers' professional characteristics that hinder performance of students in Social Studies. This, they could do by supervising the work of their teachers regularly in order to enhance teacher's attitude to work. They may also encourage them to attend workshops and seminars or recommend them for in-service training. When these are done, information of course and competence in method of teaching could be enhanced.

To the students of Social Studies, their performances are likely to improve as a result of this study since improved/appropriate method of teaching may also lead to better student's academic performance.

\section{LITERATURE REVIEW}

\section{The Concept of Leadership, Teacher's Role and Leadership Styles.}

There are varied meaning of the term leadership due to different perspectives and contexts within which the word is observed. According to Koontz and Weihrich (1988), leadership is seen as an art of influencing people so that they will strive willingly and enthusiastically towards the achievement of group goals. Dressler (1997) opined that leadership is the management of the human resources in order to manage their performance by inducing them to work willingly. Hersey and Blanchard (1988) also portray leadership as the activity of influencing people to strive for group objectives. Leadership is an important element in the process of direction. A leader guides and direct people towards achieving their objectives (Nyamboga, Gwiyo, Njuguna, Waweru and Nyamweya, 2014).

Cole (1997) defined leadership as a dynamic process at work in a group whereby one individual over a particular period of time and in a particular organizational context, influences the other group members to commit themselves freely to the achievement of group tasks or goals. Hoyle (2003) quoting Lunenburg asserted that observers have pondered why some successful school leaders use a consistent leadership style in all situations and others use a more situational style. Moreover, researchers seem silent in seeking answers about the impact of certain leadership styles across schools.

Davidhizar \& Cramer (2000) maintained that there have long been formal leadership roles for 
teachers as department chairs, team leaders and a variety of other positions, but titles are less important than actually functioning as effective change-agents. Teachers exhibit leadership by: Participating in professional teacher organizations, including holding positions of influence; Making student and adult learning the priority; Setting high expectations for performance; Gearing content and instruction to standards; Creating a culture of continuous learning for adults; Using multiple sources of data to assess learning; Activating the community's support for school success; Taking part in school decisions, including working on teams with administrators to plan school improvements; Defining what students need to know and be able to do, including developing standards for curriculum and assessments; Sharing ideas with colleagues, including leading professional development programs for colleagues; Being a mentor to new teachers. Helping to make personnel decisions, including the hiring of new teachers and administrators; Improving facilities and technology; Working with parents, including the development of better links between schools and homes; Creating partnerships with colleges and universities to prepare future teachers; Becoming leaders in the community, and Leading efforts to make teachers more visible and communicate positive information.

Researchers have also identified three styles of leadership (Wiles, 1990; Liberman, Berverly and Alexander, 1994). These include the Autocratic, Democratic and Laissez-faire leadership styles. The autocratic leadership style is also known as the authoritarian style of leadership. Here, power and decision making resides in the leader. The leader direct group members on the way things should be done. The leader does not maintain clear channel of communication between self and clear channel of communication between self and the subordinates. He does not delegate authority nor permit subordinates to participate in policy making (Symalic and Jack, 1990; Hoy and Miskel, 1992; John, 2002).

Fred (2001) stated that in a democratic system the students are surely involved in any efforts aimed at finding solution to the problems and planning the classroom of the organization. The leader in this style makes for easy flow of information to dispel remours and also provide avenue of steady feedback mechanism. Vain (2000) emphasized that a democratic leader does not normally takes arbitrary orders and decision as he regards the subject as partner in progress. He is always mindful and sensation to the needs and welfare of the staff and strives always to motivates them. A teacher with democratic leadership style employs guidance in decision making, especially decision affecting his class by giving paramount attention their feelings by sharing information and creating a pleasant working relation in the classroom. Kojo (2001) avers that that "in conflict management and resolution, the democratic leader will usually employ wide consultation, dialogue, persuasion and above all, compromise as veritable tools for achieving a stable and enduring tranquility within the system". At all times, the democratic leader makes available his advice and suggestion to his class. The democratic style of leadership on the other hand emphasizes group and leader participation in the making of policies. Decisions about organizational matters are arrived at after consultation and communication with various people in the organization. The leader attempts as much as possible to make each individual feel that he is an important member of the organization (Heenan and Bemnis, 1999). In this style of leadership, a high degree of staff morale is always enhanced (Mba, 2004).

Laissez-faire leadership style allows complete freedom to group decision without the leader's participation. Thus, subordinates are free to do what they like. The role of the leader is just to supply materials. The leader does not interfere with or participate in the course of events determined by the group (Talbert and Milbrey, 1994). According to Yilmax (2009) Laissez-faire classroom management is a style where teachers display little behaviour to control students and demand little from them. In this style, teachers accept and watch students' behaviours and reactions, and never hurt their feelings and emotions and hardly say "no" to their students. In this style, there is no continuous discipline, teachers become friendly with students at once and really appreciate them, plus treat their students in a friendly manner. Teachers have difficulties in refusing student's demands. However, in this style, innocuous behavior of teachers may lead to uncontrolled students actions and occasionally classes get out of control. Teachers with this style are much loved by their students.

Therefore, Okoroji, et al (2014) in a research examined the effect of leadership styles on teaching and learning process. The population comprises the academic staff of selected secondary schools in Owerri North Local Government Area (LGA). The academic staff members selected includes junior and senior staff 
members, as well as male and female staff. Sixty-six teachers, which constitute the population of academic staff selected from secondary school makes up the sample for the study. Stratified random sampling technique was used for sample selection. Self-structured questionnaire was the instrument used for data collection. The method of data analysis used on this research work is ANOVA statistics. Based on the summary of the findings, Gender to a high extent, influences the leadership style used in classroom teaching and learning process. The result also reveals that majority of secondary school teachers in Owerri North used democratic leadership style more than other types of leadership styles. Having listed some findings of the research work, it is necessary to make recommendation. Both male and female teachers should be exposed to constant and relevant seminars, workshop by the school management boards in order to ensure that these teachers are equipped with better understanding of leadership style as well as better combination of these styles.

In furtherance to these, Yusuf (2012) carried out a study to investigate the influence of principal's leadership styles on students' academic achievement in secondary schools in Osun State. The descriptive survey design was employed on a sample of 50 school principals from randomly selected schools. The findings of the study revealed that autocratic leadership style had a negative influence on students' academic achievement while democratic styles however had a positive influence on students' academic achievement. Laissez-faire leadership style had no significant influence on students' achievement. Based on this finding, school principals were encouraged to adopt the effective style of leadership.

Similarly, Nyamboga et al (2014) in their research to determine leadership styles on the performance of public secondary schools in National Examinations in Tana, Kenya used nine secondary schools in the region and compare their performances from 2003 to 2009. Forty respondents were selected using the simple random sampling and the findings revealed that a positive relationship between principals leadership styles and student's performance. Autocratic style was found to have negative effect on the students' performance in national examinations.

Moreso, Drobot and Rosu (2012) carried out another study on teachers' leadership style in the classroom and their impact upon high school students in Romania. The result from their study were not significant as they asserted that one may not claim that one leadership style is the best for better or higher students' academic achievement but situational. To Drobot and Rosu, the portrait of the ideal teacher is not only based on the teacher's communication and relationship skills but on the quality of explanations and teaching (pedagogic talent). Similarly, Duze (2012) study investigated the leadership styles of principals and the effect on job performance of teachers and supportive staff in senior secondary schools in Delta State of Nigeria. The population comprised all 358 senior secondary schools in the State from which a sample 120 was selected through the simple random sampling technique. Three instruments were used for data collection principals' leadership style questionnaire (PLSQ), teachers' (TJPQ) and supportive staff (SSJPQ) job performance questionnaires. The data collected were analyzed using frequencies, percentages, ANOVA, and regression statistics. Results showed that autocratic leadership style was the most commonly used among principals of senior secondary schools in Delta State, followed by laissez-faire, and lastly democratic. Job performance was found to be low for both categories of staff in the three leadership variables. Interestingly, supportive staff indicated highest level of job performance under laissezfaire principals and lowest under autocratic principals. For teachers job performance was highest under democratic and lowest under autocratic principals. Also, job performance of staff was found to be more significantly related to democratic leadership style than either autocratic or laissez-faire leadership style. It was therefore recommended that principals should adopt the democratic leadership style to boost better job performance among staff and in essence enhance administrative effectiveness and students' academic performance.

Adeyemi (2010) carried out a study to investigate principal's leadership styles and teacher's job performance in senior secondary schools in Ondo State, Nigeria. 281 secondary schools were used out of this population, a sample of 7460 teachers were used. It was found that democratic leadership style yielded a higher teacher job performance compared to other styles. It was therefore recommended that the use of autocratic and laissez-faire leadership styles by principals should be discouraged as much as possible in schools as high teachers performance could also translate to high academic achievement of students. 
Moreover, Tilmaz (2009) in a study to ascertain primary school teachers' views about pupil control ideologies and classroom management styles in Turkey used a sample of 200 primary school teachers from Kutahya's Province Turkey. Using the "Classroom Management Profile Scales" and pupil ideology scale data were collected and analysed and the findings from the study showed that no one best styles is appropriate for any class situation.

\section{RESEARCH QUESTIONS}

The following research questions were put forward:

i. How does teachers' autocratic leadership style influence students' academic achievement in Social Studies?

ii. To what extent does Social Studies teacher's democratic style influence students' academic achievement?

iii. How does teachers' laissez-faire leadership style influence students' academic achievement in Social Studies?

\section{RESEARCH HYPOTHESIS}

The following hypotheses were formulated to guide the study:

i. Social Studies teachers' autocratic leadership style does not significantly influence students' academic achievement.

ii. There is no significant influence of teachers' democratic leadership style on students' academic achievement in Social Studies.

iii. Social Studies teachers' laissez-faire leadership style does not significantly influence the academic performance of students.

\section{METHODOLOGY}

The study adopted the ex-post facto research design since the effect of the independent, variables on the subjects has already occurred; the researcher has no control over it. The population of the study consisted of all JSS 3 Social Studies students in public secondary schools in Calabar Metropolis (Calabar South and Calabar Municipality) totalling 6461 students as gotten from the State Secondary School Education Board.

Using the simple random sampling, the researcher selected six schools and from the six schools, a sample of two hundred JSS 3 Social Studies students was used for the study.

The researcher utilized two instruments for the study; Social Studies Teachers Leadership Styles Questionnaire (STLSQ) and the Social Studies Achievement Test (SOSAT) the STLSQ was used to measure the teachers leadership styles variables while the Social Studies achievement test was used to determine the student's academic achievement.

The instruments were subjected to validity and reliability. To establish the validity, the researcher consulted research specialist in measurement and evaluation to ensure that the instrument measure what it was expected to measure. For the reliability, a pilot test of the instrument was carried out using a sample of twenty students outside the research area. After the trial test, the data were analysed and it was found out that the instrument was reliable enough for data collection as it yielded a co-efficient of 0.08 using the Kuder Richardson method.

The instruments were administered at to the Social Studies students after due permission was taken from the respective school principals, there were then retrieved for analysis. It had one hundred per cent retrieval.

\section{RESULTS.}

TABLE 1: One-way Analysis of Variance (ANOVA) of the Influence of Teachers' Leadership Styles on Academic Performance of Students.

\begin{tabular}{lllll}
\hline Groups & $\mathrm{N}$ & $\overline{\mathrm{X}}$ & $\mathrm{SD}$ \\
\hline Democratic L.S & 123 & 34.74 & 3.01 \\
Authoritarian L.S & 35 & 33.20 & 2.47 \\
Laissez-faire L.S & & 42 & 32.50 & 2.98 \\
\hline Total & 200 & & 3.05 \\
\hline Source of variance & $\mathrm{SS}$ & $\mathrm{Df}$ & $\mathrm{Ms}$ & $\mathrm{F}$ \\
\hline Between group & 184.23 & 2 & 92.11 & $10.95^{*}$ \\
Within group & 1655.77 & 197 & 8.41 & \\
Total & 1840.00 & 199 & & \\
\hline
\end{tabular}

P.05, $d f=2,197$, critical $F=3.06$ 
The result of the analysis presented in table 1 revealed that the calculated $\mathrm{F}$-value of 10.95 is statistically greater than the critical $\mathrm{F}$-value of 3.06 at 0.05 level of significance with 2 and 197 degrees of freedom. With this result, the null hypothesis was rejected while the alternate hypothesis was upheld. Based on the significant
F-value, a detailed multiple comparison analysis using fisher's least square difference (LSD) analysis will done in order to show the independent groups between which the significant difference lies. The result of the analysis presented in table 2 .

TABLE 2: Fisher's Least Square Difference (LSD) Multiple Comparison Analysis of the influence of teachers' leadership styles on academic performance of students.

\begin{tabular}{llll}
\hline Teachers leadership style & Democratic $(\mathrm{N}=123)$ & $\begin{array}{l}\text { Authoritarian } \\
(\mathrm{N}=35)\end{array}$ & $\begin{array}{l}\text { Laissez- } \\
\text { faire }(42)\end{array}$ \\
\hline Democratic LS & $34.74 a$ & $1.54 \mathrm{~b}$ & 2.24 \\
Authoritarian LS & $2.77 \mathrm{c}$ & 33.20 & 0.7 \\
Laissez-faire LS & 4.32 & 1.05 & 32.50 \\
\hline
\end{tabular}

\section{Note:}

a) Group means are placed along the diagonal

b) Differences between group means are placed above the diagonal

c) Fisher's LSD t-values are placed below the diagonal

The result of analysis presented in Table 2 indicate that the significant difference lies among the academic performance of students taught with the three teachers' leadership styles but the highest significant difference lies between students taught by teachers with autocratic and laissez-faire leadership styles with LSD value of 4.32 while students taught by teachers with democratic leadership style preformed academically better than those of other groups with mean value of 34.74 . This was followed by students taught by teachers with authoritarian leadership style with mean value of 33.20 while students taught by teachers with laissez-faire leadership style have the mean of 32.50. The implication of this result is that there is a significant influence of leadership style of teachers on academic performance of students in Social Studies in Calabar Metropolis.

\section{DISCUSSION OF FINDINGS}

The study results showed that students taught by teachers with democratic, authoritarian and laissez-faire leadership styles differ in terms of academic performance. The finding of this study is in accordance with the finding of the earlier study of Yusuf (2012) and the influence of principal leadership styles and students' academic achievement in secondary schools in Osun State, Nigeria. The study the adopted the descriptive survey design and a sample of 50 school principals revealed that authoritative leadership has a negative effect on students' academic achievement while democratic leadership however had a positive influence on students' academic achievement. This result is also in support of the findings of Okoroji et al (2014) whose result revealed that majority of the secondary school teachers in Owerri North the students' academic achievement in the research area was high because majority of the teachers used democratic leadership style.

However, the result of the study is at variance with the result of findings of Drobot and Rosu (2012) and Duze (2012) which revealed nonsignificant influence of leadership styles on students' academic achievement. To Drobot and Rosu, the portrait of the ideal teacher is not only based on the teacher's communication and relationship skills but on the quality of explanations and teaching (pedagogic talent). However, the researcher of the view that this variations maybe due to the cultural and psychological differences and other variables combined that exist in the research areas.

\section{CONCLUSION}

In conclusion, it is pertinent to note that the leadership style of a teacher contributes immensely to the success of teaching and learning in schools. Therefore, irrespective of the disposition of the teachers, effort should be geared towards creating a friendly teacherstudent atmosphere and relationship for learning/change in behaviour. 


\section{RECOMMENDATIONS}

Based on the implications of the findings, the following recommendations are made.

1. Social Studies teachers should imbibe more of democratic than autocratic or laissez faire leadership styles in their classrooms to enhance students' academic achievement.

2. Educational administrators should also ensure that teachers at their recruitment stage be given appropriate orientation on instructional delivery strategies and classroom management for better students' scholastic outcomes.

3. The Cross River State secondary school education management board should organize seminars and workshop for teachers on proper classroom management.

\section{REFERENCES.}

Adetula, L. O., 1993. Different Facets of Research on Effective Teaching. Journal of Studies in Curriculum 4 (1\&2): 33-47.

Adeyemi, T. O., 2010. Principals Leadership Styles and Teachers' Job Performance in Senior Secondary School in Ondo State,

Nigeria. Current Research Journal of Economic Theory 3(3), 84-92.

Cole, G. A. (1997) Personnel Management $\left(4^{\text {th }}\right.$ ed.) London: Ashford Colocur Press.

Davidhizar, R., and Cramer, C., 2000. Gender differences in leadership in the health Professions. Health Care Manager, 18(3), 18-24.

Duze, C. O., 2012. Leadership Styles of Principals and Job Performance of Staff in Secondary Schools in Delta State of Nigeria. International Journal of Arts and Humanities. Ethiopia: Bahir Dar, 1 (2), 224-245

Dressler, G., 1997. Human Resource Management. $\left(19^{\text {th }}\right.$ ed.) Prentice Hall, Upper Saddle.

Drobot, L. and Rosu, M., 2012. Teachers Leadership Style in Classroom and their Impact upon High School Students. A paper presented at International Conference of Scientific paper AFASES 2012 Brasou $24^{\text {th }}-26^{\text {th }}$ May.
Ekici, G., 2004. Assessment of Teachers Classroom Management Profiles in the first-level Elementary Education. TED Journal of Education and Science. 29 (131), 50-60.

Federal Republic of Nigeria 2004. National Policy on Education ( $4^{\text {th }}$ ed.) Lagos: NERDC Press.

Fred, YL, 2001 Looking into the classroom. New York: Hamper and Row Publishers.

Good, L. T, and Brophy, J., 1995. Contemporary educational psychology (5th ed.). New York: Longman Publishers.

Heenan, D. A. and W. Bennis 1999. Co-Leaders; the Power of Great Partnership. New York: John Wiley and Sons.

Hersey, P. and Blanchard, C., 1988. Management of Organisational Behaviour: Utilizing Human Resources ( $3^{\text {rd }}$ ed.) New Jersey: Prentice-Hall.

Hoy, N. K. and Mishel C. G., 1992. Educational Administrative Theory, Research and Practice. New York: Random House.

Hoy, W. K. and Mishel, G. G, 2001. Educational Administration: Theory Research and Practice. New York: Randon House.

John, C. M., 2002. Million Leaders Mandate. Notebook one. USA: Equip Publishers.

Kojo, O., 2001. Integrating the Nigeria Teacher: The New approach to teaching. Warri: Human books.

Liberman, A. F. Beverly, A and Alexander C., 1994. A culture in the making. Leadership in Learner-centred schools. New York: National Centre for Restructuring Education.

Mba, J., 2004 Strategic Management Centre. Punch PP. A. 24

Mkpa, M. A., 2005 A Keynote Address on Challenges of Implementing the School Curriculum in Nigeria. Nigerian Journal of Curriculum Studies. 12(1):9-17. 
Nyamboga, T. O. Gwiyo, J. S. Njuguna F. W., Waweru, S. N., and Nyam Weya, B. O., 2014. A Critical Review of the Leadership styles on the Performance of Public Secondary Schools in National Examination in Tara River Country. Journal of Education and Practice. 5(22), 197-220.

Odey, E. O., 2014. Teacher Variables and Academic Performance of Secondary School Students in Social Studies in Calabar Education. Zone Cross River State, Nigeria. Unpublished M.Ed Thesis, University of Uyo, Uyo.

Odey, E. O. and Odey, E. E., 2018. Social Studies Undergraduate Students Variables and their Attitude Towards Examination Malpractice in the University of Calabar, Calabar Cross River State. International Journal of Contemporary Social Science Education (IJCSSE). 1(2), 248-256.

Odey, E. E and Odey, E. O., 2019. Constraints of Effective Teaching and Learning of Social Studies Education in Nigeria. International Journal of Contemporary Social Science Education (IJCSSE). 2(1), 19-24.

Okoroji, L. I., Anyanwu, O. J., and Ukpere, W. I., 2014. Impact of Leadership Styles on Teaching and Learning Process in Imo State. Mediterranean Journal of Social Sciences, Rome-Italy: 5(4), 180-193.
Paun, E., 1999. The School in Socio-pedagogic Approach. Lasi: Polirom publishing House.

Retrieved at htpp://www.grpjournal.org/Journal/catego ry/JOIRMAH. aspex

Symlie, M. A. and Jack W. D., 1990. Teacher Leadership Tension and ambiguities in Organisational Perspective. Journal of Education Administration Quarterly. 26(1) 235-259.

Udoukpong, B. E. Emah, I. E. and Okon C. P., 2006. Social Studies as a Vehicle for Civilizenship Education in Nigerian Primary Schools in the $21^{\text {st }}$ Century Nigerian. Journal of Curriculum Studies, 13 (2): 175-178.

Wiles, K., 1990 Supervision for Better Schools. New Jersey: Eagleword Clifs.

Yilmax, K., 2009. Primary School Teachers view about pupil control ideologies and Classroom Management Styles. Cyriot Journal of Educational Sciences 4(9), 157-167.

Yusuf, A. E., 2012. Influence of Principals Leadership styles on Students Academic Achievement in Secondary Schools. Journal of Innovative Research in Management and Humanities 3(1), 113121

Vain, R., 2000. Role playing method in the classroom. Chicago: Science Research Association. (Related project work, personal collection). 